\title{
Antibodies against Pax6 Immunostain Amacrine and Ganglion Cells and Neuronal Progenitors, but not Rod Precursors, in the Normal and Regenerating Retina of the Goldfish
}

\author{
Peter F. Hitchcock, ${ }^{1}{ }^{*}$ Rachel E. Macdonald, ${ }^{2}$ Jeff T. VanDeRyt, ${ }^{1}$ and Stephen W. Wilson ${ }^{2}$ \\ ${ }^{1}$ W. K. Kellogg Eye Center, Department of Ophthalmology, University of Michigan, Ann Arbor, Michigan \\ 48105, and ${ }^{2}$ Developmental Biology Research Center, Randall Institute, Kings College London, \\ London, WC2B 5RL United Kingdom
}

\begin{abstract}
SUMMARY
Pax6 is a developmental regulatory gene that plays a key role in the development of the embryonic brain, eye, and retina. This gene is also expressed in discrete groups of neurons within the adult brain. In this study, antibodies raised against a fusion protein from a zebra fish pax6 cDNA were used to investigate the expression of the pax6 gene in the mature, growing, and regenerating retina of the goldfish. On western blots of retinal proteins, the pax6 antibodies recognize a single band at the approximate size of the zebra fish pax6 protein. In retinal sections, the antibodies label the nuclei of mature amacrine and some ganglion cells. At the retinal margin, where neurogenesis and cellular differentiation continually occur in goldfish, the antibodies label neuronal pro-
\end{abstract}

\section{INTRODUCTION}

Identifying the expression patterns of developmental regulatory genes during brain development is essential for understanding the molecular mechanisms that create spatial domains or specify the fates of individual neurons. Equally important, but less extensively studied, is identifying the patterns of gene expression in the adult brain following injury and during regeneration. The retina of the

Received April 27, 1995; accepted November 2, 1995

Journal of Neurobiology, Vol. 29, No. 3, pp. 399-413 (1996)

(C) 1996 John Wiley \& Sons, Inc.

CCC 0022-3034/96/030399-15

* To whom correspondence should be addressed. genitors and the newly postmitotic neurons. Following injury and during neuronal regeneration, the antibodies label mitotically active progenitors of regenerating neurons. Rod precursors, proliferating cells that normally give rise solely to rod photoreceptors and are the presumed antecedents of the injury-stimulated neuronal progenitors, are not immunostained by antibodies to the pax6 protein. The results of this study document the identity of pax6-expressing cells in the mature retina and demonstrate that in the goldfish pax 6 is expressed in neuronal progenitors during both retinal growth and regeneration. (c) 1996 John Wiley \& Sons, Inc.

Keywords: pax genes, transcriptional regulators, brain injury, cell proliferation, immunocytochemistry. goldfish is a well-established model for studying growth and plasticity of the central nervous system (CNS), but it is also a useful model for studying neuronal regeneration and CNS wound healing. Injury to this tissue stimulates regenerative neurogenesis (Lombardo, 1968, 1972; Raymond et al., 1988; Hitchcock et al., 1992), a process that perhaps engages, in the adult tissue, molecular events characteristic of embryonic development.

The ability of the goldfish's retina to regenerate neurons is doubtless related to the persistent growth and plasticity of this tissue. The retinas of many teleost fish grow continuously by two welldescribed processes: the extant retina expands in a balloon-like fashion (Lyall, 1957; Ali, 1964; Johns and Easter, 1977; Kock, 1982), accompanied by neuronal growth (Bloomfield and Hitchcock, 
1991), and new neurons are added, both appositionally and interstitially (Müller 1952; Blaxter and Jones, 1967; Johns, 1977, 1982; Meyer, 1978; Raymond, 1985; Raymond and Rivlin, 1987; Fernald, 1989; Sandy and Blaxter, 1980; Hagedorn and Fernald, 1992). The apposition of new neurons occurs at the retinal margin from a ring of neuroepithelial cells, referred to here as the germinal zone. Rod photoreceptors are added interstitially from a separate population of neuroepithelial cells, known as rod precursors, that are scattered throughout the outer nuclear layer (ONL) (Johns and Fernald, 1981). As the eye grows and the retinal surface expands, new rods are inserted into the existing lawn of photoreceptors, keeping the rod photoreceptor density roughly constant as the retina grows (Johns, 1982). Few, if any, rod photoreceptors are generated at the germinal zone (Raymond and Rivlin, 1987; Fernald, 1989). Any insult that significantly depletes retinal neurons stimulates regenerative neurogenesis (Lombardo, 1968, 1972; Maier and Wolburg, 1979; Kurz-Isler and Wolburg, 1982; Negishi et al., 1987; Raymond et al., 1988; Hitchcock et al., 1992; Braisted and Raymond 1992, 1993; Braisted et al., 1994). For example, as in the study described here (see also Hitchcock et al., 1992; Lombardo, 1968), surgical excision of a small piece of retina stimulates the formation of a blastema of neuroepithelial cells at the wound margin that migrates into the wound, appositionally adding new retina to the old. Experimental evidence suggests that rod precursors are the origin of the regenerated neurons (e.g., Raymond et al., 1988), although the potential contribution of other mitotically competent cells in the retina has recently been proposed (Braisted et al., 1994).

Virtually nothing is known about genes that regulate the ongoing neurogenesis in the adult goldfish retina or the neurogenesis stimulated by injury. Several goldfish cDNAs encoding homeobox genes expressed in the retina have been identified (Levine and Schechter, 1993), but only VSX-1 has been analyzed in any detail, and it appears not to be directly involved in neurogenesis (Levine et al., 1994). In contrast, in other vertebrates several developmental regulatory genes have been identified that are expressed during retinal neurogenesis (Beebe, 1994; Liu et al., 1994). Prominent among these, by virtue of its highly conserved structure and pattern of expression in vertebrates, is pax6, a member of the family of pax genes.

Pax genes contain a conserved coding domain, the paired box, which was first identified in the
Drosophila segmentation gene, paired (Frigerio et al., 1986; see also Bopp et al., 1986). The products of pax genes are DNA-binding transcription factors (for reviews, see Noll, 1993; Strachan and Read, 1994), which when mutated result in wellcharacterized syndromes in both mice (undulated, Balling et al., 1988; Splotch, Epstein et al., 1991; Small eye; Hill et al., 1993; Krd, Keller et al., 1994) and humans (Aniridia, Glaser et al., 1992, and Jordan et al., 1992; optic disc colobomas, Sanyanusin et al., 1995) that are characterized by their semidominance (Gruss and Walther, 1992). Since its initial identification in the mouse (Walther and Gruss, 1991), pax6 homologues have been identified in the rat (Matsuo et al., 1993), Drosophila (Quiring et al., 1994), humans (Ton et al., 1991), zebra fish (Krauss et al., 1991; Püschel et al., 1992), birds (Martin et al., 1992; Goulding et al., 1993 ) and urodele amphibians (Del Rio-Tsonis et al., 1995). In Drosophila, the pax6 homologue, eyeless, controls eye development (Halder et al., 1995).

In the embryonic vertebrate eye, pax6 is expressed in the retina, cornea, and lens, tissues of ectodermal origin (Walther and Gruss, 1991). During retinal development, pax6 is expressed in proliferating cells throughout the neuroepithelium, and as neuronal differentiation proceeds, pax6 expression is progressively restricted to cells in the inner nuclear and ganglion cell layers (Walther and Gruss, 1991; Krauss et al., 1991; Püschel et al., 1992; Stoykova and Gruss, 1994; Macdonald and Wilson, personal communication ).

If pax6 plays a role in embryonic retinal development, we reasoned that this gene should also play a role during the continuous growth of the fish retina and during retinal regeneration, which we hypothesized recapitulates many events of normal retinal ontogeny (Raymond, 1991; Hitchcock and Raymond, 1992; Hitchcock and Cirenza, 1994; Hitchcock and VanDeRyt, 1994). To investigate these possibilities, we used affinity-purified polyclonal antibodies generated against a recombinant zebra fish pax6 protein (Macdonald et al., 1994a) to identify cells containing the goldfish pax 6 protein in immunostained sections from normal retinas and retinas that received surgical lesions (Hitchcock et al., 1992). As part of this investigation, we also identified the differentiated neurons in the mature retina that express pax 6 . The immunostaining revealed that in the mature retina pax6 is expressed in amacrine and some ganglion cells. At the retinal margin pax 6 is expressed in the mitotically active cells of the germinal zone and newly 
postmitotic neurons. Following retinal injury, pax6 is expressed in proliferating cells of the regenerative blastema at the retinal wound. In contrast to its expression in the mitotically active cells of the germinal zone and blastema, pax6 is not expressed in rod precursors.

Preliminary results of this study have been published previously (Macdonald et al., 1994b; Hitchcock et al., 1994).

\section{MATERIALS AND METHODS}

\section{Animals}

Goldfish, 3 to 4 inches standard length, were purchased from Grassy Fork Fisheries (Martinsville, IN) and housed in 10 gallon aquaria kept at approximately $28^{\circ} \mathrm{C}$. Lighting was maintained on a 12:12 h light/dark cycle, and the fish were fed daily. Prior to all surgeries and death, fish were deeply anesthetized in tricaine methane sulfonate (MS222; Sigma). Fish were killed by exsanguination under deep anesthesia.

\section{Western Blots}

Fish were dark adapted for at least $1 \mathrm{~h}$, and 10 retinas were isolated by dissection from the surrounding ocular tissues [see Hitchcock and Easter (1986) for a more detailed description of the retinal dissections). The retinas were homogenized in extraction buffer $(50 \mathrm{~m} M$ Tris$\mathrm{HCl}, 50 \mathrm{~m} M$ sodium chloride $\mathrm{NaCl}, 5 \mathrm{~m} M$ magnesium chloride, $250 \mathrm{~m} M$ sucrose, proteinase inhibitor) and centrifuged twice (homogenate, $1400 \mathrm{~g}$ for $10 \mathrm{~min}$; supernatant at $100,000 \mathrm{~g}$ for $(\mathrm{h})$. The pellet from the second centrifugation was resuspended in $250 \mathrm{~m} M$ trisaminomethane base (containing sodium dodecyl sulfate), $\beta$ mercaptoethanol, glycerol, and bromophenol blue) and solubilized by sonication. Thirty micrograms of retinal proteins/lane and protein standards were separated by electrophoresis in 10\% SDS-polyacrylamide gel and transferred to nitrocellulose.

Strips of nitrocellulose were incubated in $0.1 \mathrm{M}$ phosphate buffer, $\mathrm{pH} 7.5$, with $0.1 \%$ Triton $\mathrm{X}-100$ (PBT) plus $3 \%$ normal goat serum (NGS) for $1 \mathrm{~h}$ at room temperature. Incubation in primary antibodies was done overnight at $4^{\circ} \mathrm{C}$ in PBT plus NGS. Control strips were incubated overnight in PBT and NGS with an equivalent amount of protein from normal rabbit serum. All strips were washed three times for $15 \mathrm{~min}$ in PBT and incubated at room temperature for 2 to $3 \mathrm{~h}$ in anti-rabbit secondary antibodies conjugated to peroxidase. Strips were washed (see before) and the reaction product was developed using a chemiluminescence detection method (Amersham) according to the manufacturer's directions. Immunostaining western blots was performed twice, and similar results were obtained both times.

\section{Retinal Lesions, BrdU Injections and Tissue Processing}

Retinal lesions were made according to Hitchcock et al. (1992). In brief, three full-thickness incisions were made in the dorsonasal pole of the globe to create a tongueshaped flap. The flap was reflected outward and the overlying retina (generally 1 to $2 \mathrm{~mm}^{2}$ ) was gently teased free of the retinal pigmented epithelium, cut at its base, and removed. A single suture was used to close the scleral flap, and the fish were revived and returned to their home tanks. Lesions were made in the eyes of 14 animals ( 28 retinas) and divided into six groups with survival times at $3,5,7,14,28$, and 56 days. Twenty-four hours prior to sacrifice, eyes were injected intravitreally with $2 \mu \mathrm{l}$ of $1 \mathrm{~m} M$ 5-bromo-2'-deoxyuridine (BrdU; Becton-Dickinson). On death, all eyes were enucleated, the cornea and lens of each were removed, and the eye cups were fixed by immersion for $1 \mathrm{~h}$ in $4 \%$ paraformaldehyde in $100 \mathrm{~m} M$ phosphate buffer, $\mathrm{pH} 7.2$ to 7.4. Eye cups were infiltrated in sucrose and OCT, frozen, and $10 \mu \mathrm{m}$ thick sections through the lesion were cut on a cryostat and collected on slides coated with TESPA (3-aminopropyltriethoxy silane; Sigma). For each lesioned eye, a sample slide was processed for BrdU immunocytochemistry to confirm that the BrdU injection was successful. Because of a limited supply of the pax 6 antibodies, sections from one eye at survival times of $3,14,28$, and 56 days and sections from two eyes at survival times of 5 and 7 days were selected for pax6/BrdU immunocytochemistry. Two eyes were examined at 5 and 7 days postlesion, because these times mark the onset of the injury-induced cell proliferation (Hitchcock et al., 1992). All sections were stored at $-80^{\circ} \mathrm{C}$ or on dry ice until useci for immunocytochemistry. A total of 184 sections were immunostained and examined.

\section{Ganglion Cell Labeling}

Ganglion cells were retrogradely labeled with the fluorescent tract tracer, propidium iodide (Sigma) by applying a small pledget of Gelfoam soaked in a $10 \%$ solution of propidium iodide to the proximal stump of the sectioned optic nerve (Hitchcock, 1989). Two animals were allowed to survive 24 to $48 \mathrm{~h}$, and their eyes were processed for sectioning and immunostaining, as described later.

\section{Antibodies}

Combinations of monoclonal and polyclonal antibodies were used. A commercially available monoclonal antibody (Boehringer Mannheim) was used to label BrdU. A monoclonal antibody [HPC-1; provided by C. Barnstable (Barnstable et al., 1985)] was used to label putative amacrine cells. Polyclonal antibodies against pax6 [provided by I. Mikola (Macdonald et al., 1994a)] were prepared from rabbits immunized with a fusion protein 
containing the C-terminal 86 amino acids of the zebra fish pax6 protein (Macdonald et al., 1994a). All secondary antibodies (Sigma) were raised in goats and conjugated to either peroxidase, tetramethyl-rhodamine isothiocyanate (TRITC) or fluorescein isothiocyanate (FITC).

\section{Double-Label Immunocytochemistry}

Three separate double-label immunostaining experiments with two different groups of animals were performed using standard, previously described methods (Hitchcock, et al., 1992; Macdonald et al., 1994a): pax $6 / \mathrm{BrdU}$ (lesioned retinas), pax6/HPC-1 (nonlesioned retinas), and pax $6 /$ propidium iodide (nonlesioned retinas). Primary and secondary antibodies were diluted in phosphate-buffered saline (PBS), $0.5 \%$ Triton X-100, and $1 \%$ NGS and applied at room temperature to the sections for 2 and $0.5 \mathrm{~h}$, respectively. Pax 6 and BrdU immunostaining was performed sequentially. The pax6 antibodies were diluted 1:100 and visualized with secondary antibodies conjugated to peroxidase. The BrdU antibody was diluted 1:20 and visualized with secondary antibodies conjugated to TRITC. The pax6/ peroxidase immunostaining was performed first, which allowed us to monitor the diaminobenzidine (DAB) reaction product during the acid hydrolysis step of the antiBrdU immunocytochemistry. In general, the peroxidase label was only slightly degraded (in contrast to its effect on fluorescent labels). This step was followed by the BrdU immunocytochemistry. For the pax6/HPC-1 immunostaining, sections were incubated with a solution containing both primary antibodies, diluted 1:50 and 1: 20 , respectively. These antibodies were visualized with a cocktail of anti-rabbit and anti-mouse secondary antibodies conjugated to FITC and TRITC, respectively. For the pax6/propidium iodide immunostaining, sections from retinas labeled with propidium iodide were incubated with the pax 6 antibodies diluted $1: 100$ or $1: 50$ and visualized with a peroxidase-conjugated secondary antibody, as already described. Irrespective of the combination of antibodies, following the final PBS rinses, sections were coverslipped with either $70 \%$ glycerol in phosphate buffer or Gel/Mount (Biomeda Corp., Foster City, CA), photographed, and stored at $4^{\circ} \mathrm{C}$.

Because the BrdU injections also label the neuronal progenitors in the germinal zone, the lesioned eyes were used to characterize the pax6 immunostaining during retinal neurogenesis. Each immunostained section through the lesioned eyes extended from the germinal zone at one pole of the eye to the germinal zone at the other. Lesions were made adjacent to the dorsonasal pole, and the ventrotemporal pole, opposite the lesion, was considered "normal" ( see Results).

\section{RESULTS}

\section{Western Blots}

In an attempt to confirm that the antibodies against the zebra fish pax 6 protein recognize pax 6

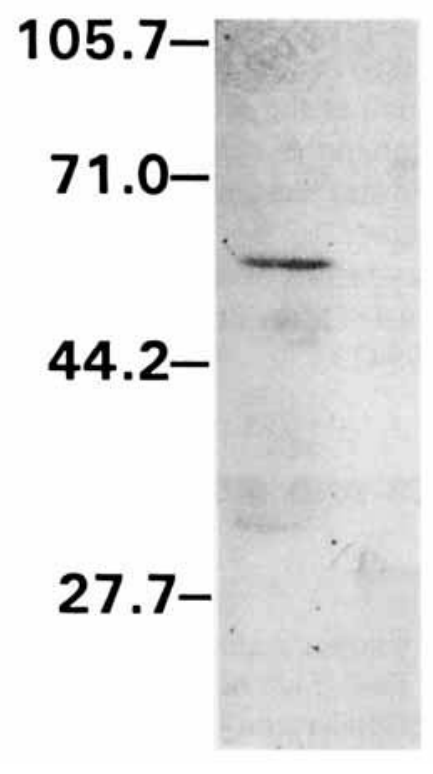

Figure 1 Western blot of goldfish retinal proteins stained with the antibodies raised against the pax 6 recombinant protein and detected with a chemiluminescence method. Relative molecular weights are indicated on the left.

from its confamilial ( Cyprinidae) relative, western blots of goldfish retinal proteins were labeled with the pax 6 antibodies. On the western blots, the antibodies recognized a single band at approximately $50 \mathrm{kD}$ (Fig. 1). This agrees with the predicted molecular mass of the zebra fish pax6 protein (Krauss et al., 1991) and the $48 \mathrm{kD}$ mass of the zebra fish protein immunoprecipitated with pax 6 antibodies (Macdonald et al., 1994a). From these results, and the pattern of immunostaining described later, we tentatively conclude that these antibodies recognize the goldfish pax 6 protein.

\section{Pax6 Immunostaining}

The pattern of immunostaining with the pax 6 antibodies was characterized in both normal retinas and retinas that received lesions (see before). In lesioned retinas, in the ventrotemporal pole of the eye away from the site of the injury, the pattern of pax 6 immunostaining was invariant across all survival times and was identical to that seen in retinas that were not lesioned. We conclude from these observations that injury to the retina did not influence the pattern of pax 6 immunostaining described here.

\section{Mature Retina}

To characterize both the staining pattern of mature retina and determine whether rod precursors were 

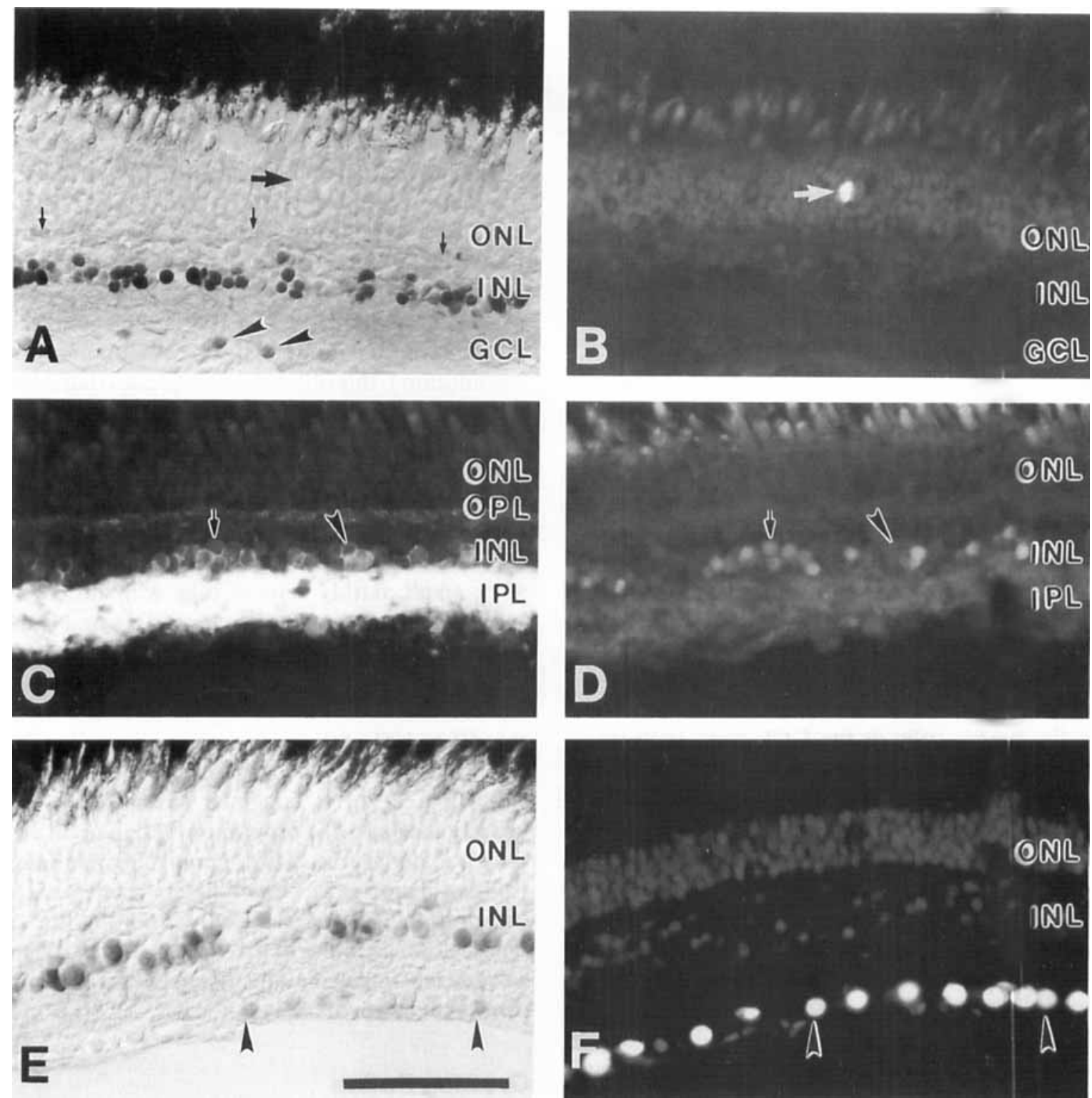

Figure 2 Photomicrographs of double-immunostained, mature retina. (A) A transmittedlight photomicrograph of pax $6+$ neurons in the INL and GCL. The small vertical arrows mark the outer border of the INL. The arrowheads identify two pax6+ cells in the GCL. (B) An epifluorescence photomicrograph showing a BrdU+ rod precursor in the ONL (white horizontal arrow). The approximate location of the rod precursor is shown by the black horizontal arrow in (A). (C) An epifluorescence photomicrograph (TRITC-conjugated secondary antibody) illustrating HPC-1 immunostained cells; (D) an epifluorescence photomicrograph (FITC-conjugated secondary antibody) of the same section illustrating pax6-immunostained cells. The arrow identifies a cluster of HPC-I-positive cells, which correspond to those pax6+ indicated by the arrow in (D). The arrowheads in (C and D) indicate HPC-1-positive cells that are not pax6+. (E) A transmitted-light photomicrograph illustrating pax6 immunostaining. (F) An epifluorescence photomicrograph illustrating propidium iodide-labeled ganglion cells in the same section. The arrowheads identify the two pax $6+/$ propidium iodide-labeled cells. Scale bar $=50 \mu \mathrm{m}$. 
labeled by the pax 6 antibodies, the central regions of retinas from $\mathrm{BrdU}$-injected eyes were examined. Figure 2(A) is a photomicrograph of a section through one of these eyes. No cell-specific immunostaining was seen when the primary antibodies were omitted (not shown). The antibodies against pax6 labeled the nuclei of cells in the vitread-half of the inner nuclear layer (INL) and in the ganglion cell layer (GCL). There was a wide range in staining intensity, although the most intensely pax6-stained (pax6+) cells were confined to the INL. Only rarely were pax $6+$ cells seen outside the vitread INL or GCL. These were small, isolated cells in the sclerad INL whose identity is not known.

Figure $2(B)$ is a fluorescence photomicrograph of the section shown in Figure 2(A) illustrating a rod precursor (arrow) that was BrdU-labeled (BrdU+). This and all other BrdU+ cells in the ONL that we identified as presumptive rod precursors were never stained by antibodies against pax 6 (pax6-).

Based on their laminar positions, we assumed that the pax6+ cells in the INL were amacrine cells and the pax6 + cells in the GCL were both displaced amacrine and ganglion cells. The identity of the pax $6+$ cells in the INL was investigated further by double-immunostaining retinal sections with antibodies for pax 6 and $\mathrm{HPC}-1$. Figure $2(\mathrm{C})$ is a fluorescence photomicrograph showing HPC-1 staining of the goldfish retina. This antibody labeled processes in both the inner (IPL) and outer plexiform layers (the former intensely, the later only lightly) and the cytoplasm of cells lying in the inner half of the INL. No HPC-1-labeled cells were seen in the GCL. This is due both to the relative rarity of displaced amacrine cells in the goldfish retina (Hitchcock and Easter, 1986) and the intense labeling of the IPL that tended to obscure cells lying at the boundaries of the nuclear and plexiform layers [Fig. 2(C)]. The pattern of immunostaining by HPC-1 suggests that in the goldfish retina this antibody recognizes an epitope in both amacrine and interplexiform cells (cells with processes in both plexiform layers) (Dowling and Ehringer, 1978). Comparisons of numerous photomicrographs of double-immunostained sections indicate that approximately $74 \%$ of the HPC- $1+$ cells (n $=194$ ) were stained for pax6 [Fig. 2(D)], suggesting that the identity of the pax6+ cells in the INL are amacrine and interplexiform cells, as was inferred from Figure 2(A). There was a significant number of HPC-1-stained cells that were not pax6+, however. If HPC-1 is a faithful marker of all amacrine and interplexiform cells (an unproven assumption ), this observation indicates that not all mature amacrine or interplexiform cells contain the pax 6 protein, although clearly the majority of them do.

In addition to labeling amacrine cells, antibodies against pax6 also label ganglion cells. Among the pax6+ cells in the GCL, two populations were seen: small, darkly stained cells with little cytoplasm, similar to pax6+ cells in the INL and lightly stained cells with round nuclei and an obvious rim of cytoplasm about the nucleus. Cell counts showed that the small, darkly stained cells constitute $5 \%$ to $10 \%$ of the pax6-immunostained cells in the GCL. Of these two groups, the lightly-stained cells [Fig. 2(A,E)] could be consistently retrogradely labeled with propidium iodide applied to the optic nerve [Fig $2(F)$ ], confirming their identity as ganglion cells. Not all lightly stained pax6+ cells in the GCL were labeled with propidium iodide, but we attribute this to the vagaries of the retrograde labeling technique, not to the presence of a third population of cells in the GCL.

\section{Growing Retina}

In the embryonic retina of the zebra fish, pax6 is expressed in mitotically active neuronal progenitors, and its expression becomes progressively restricted to differentiated neurons as retinal differentiation proceeds (Püschel et al., 1992; Macdonald and Wilson, personal communication). In the

Figure 4 Photomicrographs of retinal wounds immunostained with the antibodies raised against pax6. (A) A low-magnification photomicrograph of the retinal lesion. The double arrowheads mark the margin of the wound illustrated in $(C)$. The retinal margin is toward the right; central retina is toward the left. (B,C,D) Examples of a wound margin at 3,5, and 7 days postlesion, respectively. Note the increasing accumulation and cellular organization over time of the pax6+ cells (arrows). Abbreviations: $\mathrm{R}$, retinal pigmented epithelium; SC, scleral cartilage. Scale bar: $(B, C, D)=50 \mu \mathrm{m}$. 

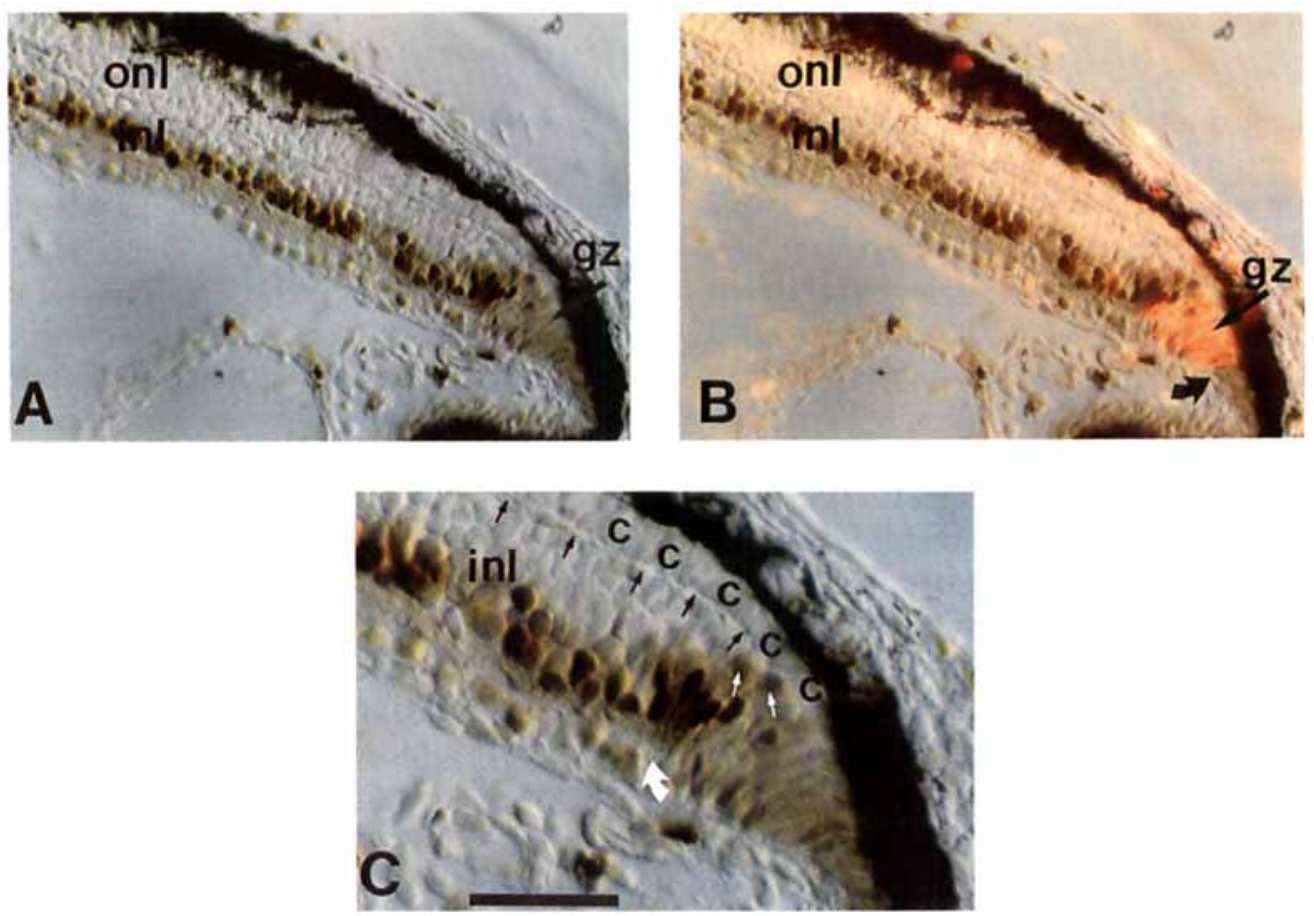

Figure 3 Photomicrographs of double-immunostained iris epithelium, germinal zone (gz), and immature retina. (A) A transmitted-light photograph showing the pax6+ cells in the germinal zone and adjacent, immature retina. (B) A transmitted light/epifluorescence, doubleexposure photomicrograph showing pax $6+/$ BrdU + double-labeled cells. The curved arrow demarcates the boundary between the germinal zone and the unpigmented iris epithelium, both of which are pax $6+$, consistent with the known widespread expression of pax 6 in the nonneural portions of the eye. (C) An enlargement of the germinal zone illustrated in (A) showing the expression pattern of pax 6 among the differentiating cells. The small white arrows indicate pax6 + cells in the outer INL (inl). The small black arrows identify the nascent outer plexiform layer separating the cone nuclei (c) from the INL. The curved white arrow indicates the nascent IPL. Abbreviation: onl, outer nuclear layer. Scale bar: $(A, B)=25 \mu \mathrm{m} ;(C)=50 \mu \mathrm{m}$.
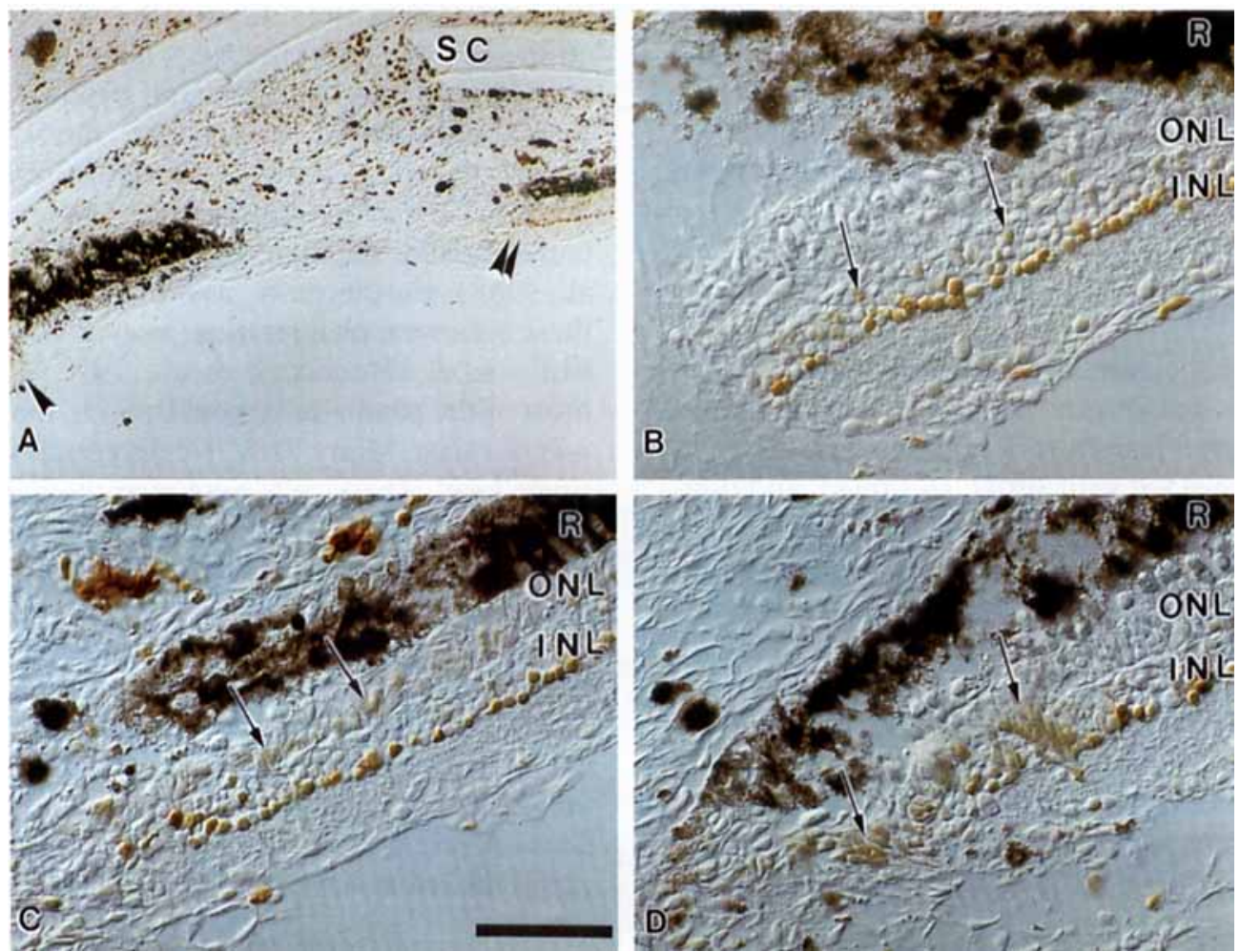

Figure 4 
retina of the juvenile and adult goldfish neurogenesis and neuronal differentiation occur continuously within narrow, nested annuli at the retinal margin (Johns and Easter, 1977), in a pattern that is qualitatively similar to embryonic retinal development. The neuronal progenitors in the germinal zone are typical of neuroepithelial cells found in the embryonic retina. They are spindle-shaped cells that span the thickness of the retina, and their chromatin is dispersed throughout the cell (Raymond and Rivlin, 1987; Fernald, 1989). To investigate the expression of pax6 during the continuous growth of the goldfish retina, the retinal margins were examined in all immunostained sections. As illustrated in Figure 3, cells of the germinal zone were lightly stained by the antibodies against pax6 [Fig. 3(A)], and in the eyes injected with BrdU all the pax6+ cells with a neuroepithilial-like morphology were also BrdU+ [Fig. 3(B)] . Just central to the pax $6+/ \mathrm{BrdU}+$ cells are newly postmitotic neurons, which, with the exception of the overlying cone nuclei [Fig. 3(C)] are all pax6+. As these cells become displaced slightly more centrally and continue to differentiate, cells in the outer half of the retina become pax6-, whereas cells in the inner half continue to be pax6+ and are separated into the INL and GCL by the developing IPL. The pattern of immunostaining at the retinal margin described before was observed in all retinal sections, from both normal and lesioned retinas. The only difference noted between the lesioned and normal retinas was the obvious hyperplasia of cells in the germinal zone adjacent to the retinal wound, a feature that is commonly observed in retinas that have been lesioned (Hitchcock, unpublished observations; see also Raymond et al., 1988).

\section{Injured/Regenerating Retina}

To establish the onset of injury-stimulated cell proliferation and determine whether the injury-stimulated neuronal progenitors express pax6, lesioned eyes were injected with BrdU, sectioned, and double-immunostained with antibodies against the pax 6 protein and BrdU. At all time points, the mature amacrine and ganglion cells at the wound margin and surrounding retina remained pax $6+$, and these cells could be readily distinguished from the injury-induced, pax $6+$ cells, which were identifiable by their location, morphology, and staining intensity ( see later). Only those cells whose pax 6 immunostaining was stimulated by the retinal injury are described here. At 3, 5, and 7 days postlesion, there was a progressive accumulation of pax6+ cells at the wound margin (Fig. 4). At 3 days postlesion, scattered pax $6+$ cells in the outer half of the INL were seen [Fig. 4(B)]. These cells were very lightly stained and had the appearance of mature neurons. Because these cells were present only adjacent to the wound, we conclude that this immunostaining is not an artifact. We do not know the identity of these cells, but their position within the INL suggests they are potentially bipolar or Müller glial cells. These cells were not labeled with $\mathrm{BrdU}$ [ there were no BrdU-labeled cells at this time (not shown )] and did not correspond in morphology or location with the first $\mathrm{BrdU}+/$ pax6 $6+$ cells (see later). Although we cannot exclude the possibility, we infer that these pax6+ cells do not contribute to the neuronal regeneration. The presumptive progenitors of regenerating neurons were first observed at 5 days postlesion [Fig. 4(C)]. These cells were pax $6+$, had a neuroepithelial-like morphology, and were present in both the ONL and INL, but were more numerous in the ONL. Five days postlesion was also the first time at which BrdU+ cells were observed, and many of the neuroepithelial-like-pax6 + cells were also BrdU+. At 7 days postlesion [Fig. 4(D)], there were many more neuroepithelial-like, pax6+ cells at the wound margin than at 5 days postlesion [Fig. $4(\mathrm{C})$ ], and these cells were present in both the ONL and INL, frequently forming radial clusters that spanned both layers. Similar to the pax $6+$ cells in the germinal zone (see before), these cells had an elongated epithelial-like morphology, they were lightly stained, and the DAB-reaction product was uniformly distributed throughout the cytoplasm. These clusters of pax $6+$ cells were similar in appearance to the "neurogenic foci" observed in ouabain-lesioned, regenerating retinas (Raymond et al., 1988). Furthermore, as illustrated in Figure 5, these cells were proliferating, as evident from their BrdU label (Hitchcock et al., 1992). Although most of the pax $6+$ cells were BrdU + , the converse was not true. Many BrdU+ cells contained only a single label. These cells were seen most frequently present within the ONL surrounding the wound [Fig. 5(A,B)], not within the regenerative blastema adjacent to the wound margin (see Discussion).

At 14 days postlesion, the wound margins remained capped with a blastema containing $\mathrm{BrdU}+1$ pax $6+$ cells, and a wedge of regenerated retina was present between the blastema and the original site of the injury. At 28 days postlesion, the injury-stimulated cell proliferation was complete, and the original gap in the retina was closed. By 56 days, the regener- 

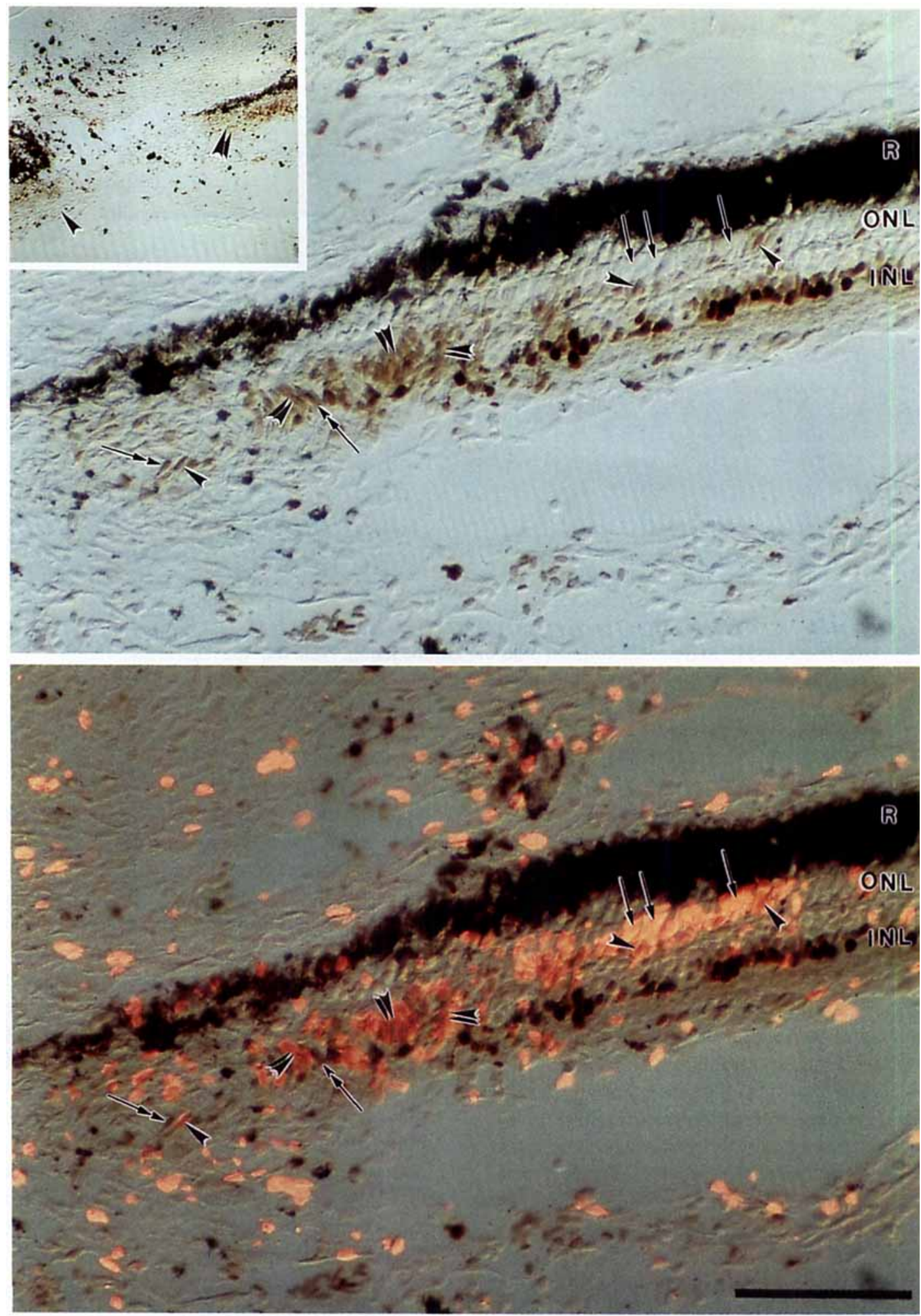

Figure 5 Photomicrographs illustrating pax6 and BrdU immunostaining at the site of a retinal injury at 7 days postlesion. (A) and the inset are transmitted-light photomicrographs. (B) A transmitted-light/epifluorescence, double exposure of the section illustrated in (A). The inset is a low magnification view of the retinal lesion. The double arrowheads indicate the segment of retina illustrated in $(A, B)$. In both $(A, B)$, the double arrowheads identify examples of clusters of double-labeled cells. This single arrowheads identify exampies of individual double-labeled cells. The long, single arrows identify cells that are immunostained for BrdU only. The long, double arrows identify cells that are immunostained for pax 6 only. Abbreviation: $R$, retinal pigmented epithelium. Scale bar $=100 \mu \mathrm{m}$. 


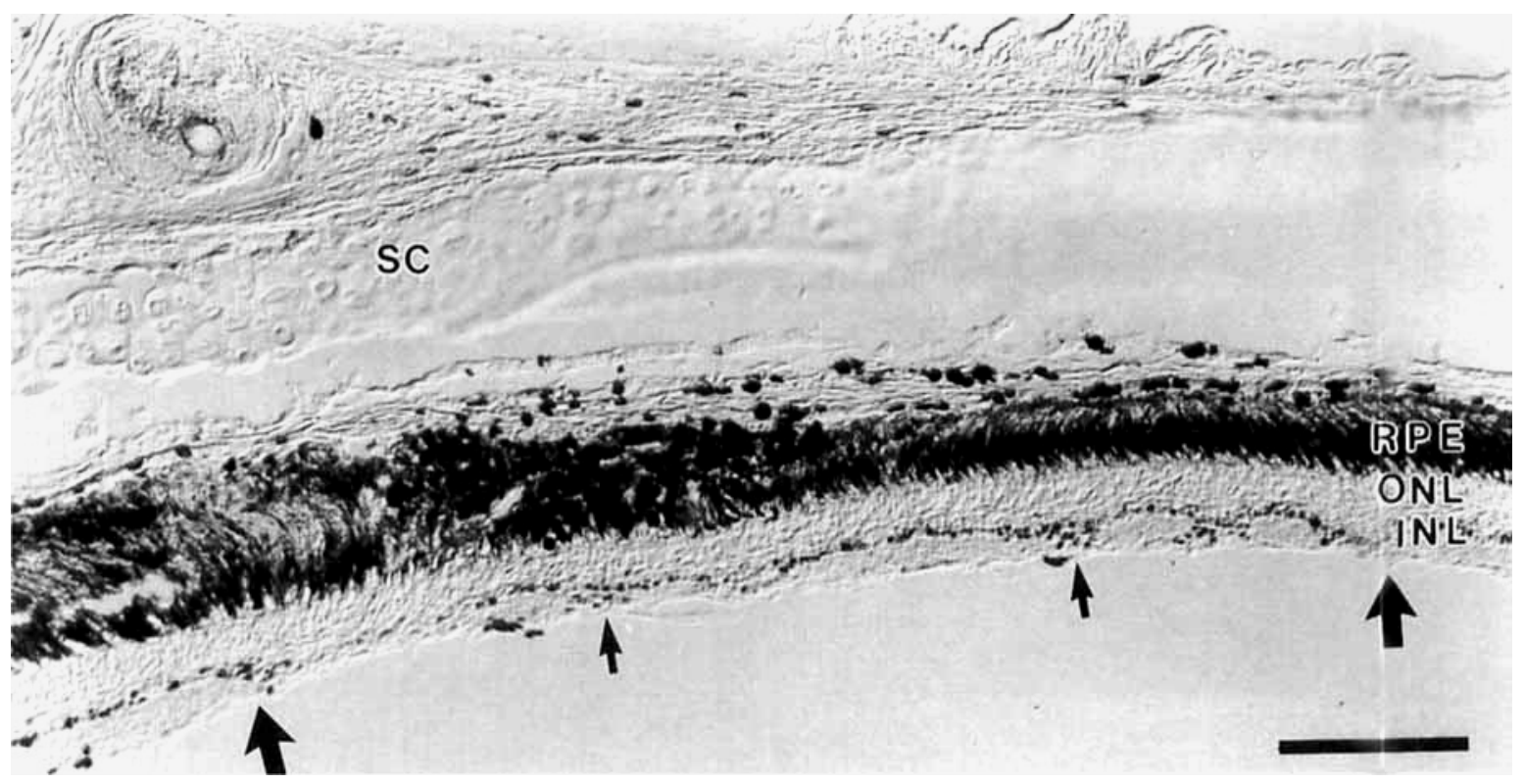

Figure 6 Low-magnification photomicrograph of regenerated retina 56 days postlesion. The large black arrows indicate the original boundary of the lesion. Note that the regenerated retina contains a relatively normal pattern of pax6+ cells, with the exceptions of the laminar fusions, which are indicated by the small black arrows. Abbreviations: RPE, retinal pigmented epithelium; SC, scleral cartilage. Scale bar $=100 \mu \mathrm{m}$.

ated retina was "mature" (Hitchcock et al., 1992) and contained all the retinal cell types, including pax6+ cells in the INL and GCL (Fig. 6).

\section{DISCUSSION}

Our data suggest that in the retina of the normal adult goldfish three populations of cells contain the pax6 protein: amacrine/interplexiform cells and ganglion cells in mature retina and neuroepithelial cells in the germinal zone at the retinal margin. Using double-immunostaining techniques, we found that the majority of cells in the INL labeled with the monoclonal antibody HPC-1, which selectively labels amacrine cells in the rodent retina (Barnstable et al., 1985), were also labeled by the antipax6 antibodies. Although we did not attempt to demonstrate conclusively that in the goldfish HPC1 is amacrine or interplexiform cell-specific, this antibody labels somata in the inner tier of the INL and processes in both plexiform layers consistent with the known position and dendritic morphology of amacrine and interplexiform cells. The co-localization of the anti-pax6 immunostaining to the HPC $-1+$ cells strongly suggests that the pax $6+$ cells in the INL are amacrine cells, and perhaps inter- plexiform cells as well. Similarly, we double-labeled cells in the GCL with a retrogradely transported marker and pax6-antibodies. This confirmed definitively that many of the pax $6+$ cells in the GCL are ganglion cells, although not every ganglion cell was pax $6+$. The pattern of pax 6 immunostaining in the mature retina of the goldfish is essentially identical to all other vertebrates examined. In the mouse (Walther and Gruss, 1991, in situ hybridization), quail (Martin et al., 1992, in situ hybridization), and zebra fish (Püschel et al., 1992, in situ hybridization; Macdonald et al., 1994b, immunostaining; Macdonald and Wilson, personal communication), cells in the inner half of the INL and GCL express the pax6 gene. Although the possibility remains that the anti-pax 6 antibodies used in this study recognize a molecule other than the goldfish pax 6 protein, the similarities in the pattern of immunostaining described here and the pattern of pax6 expression in all other vertebrate retinas examined to date strongly suggest that our antibodies are specific for goldfish pax6.

Somewhat to our surprise, rod precursors were not immunostained with the pax 6 antibodies. In the BrdU-injected eyes, rod precursors (BrdU+ cells in the ONL) were never labeled with the pax6 antibodies, and of all the sections immunostained 
for this study, only one pax $6+$ cell was observed in the ONL, and this cell was BrdU-. In the teleost retina rod precursors are thought to be the exclusive source of all rod photoreceptors (Johns, 1982; Raymond and Rivlin, 1987; Fernald, 1989). It has been debated, however, whether rod precursors are a class of neuroepithelial cells committed to a rod cell fate or whether they are pluripotent cells, more akin to those mitotically active cells in the germinal zone. In the normal retina, rod precursors cells do not express rod-specific genes (Knight and Raymond, 1990), and in the lesioned retina rod precursors are the putative source of the regenerated retinal neurons (Raymond et al., 1988; Raymond 1991). These two lines of evidence have led to the inference that rod precursors are pluripotent stem cells, and the differentiation of their progeny into rod photoreceptors is determined by cell-cell interactions within the local microenvironment of the ONL (see also Mack and Fernald, 1995). Although the absence of pax 6 in rod precursors cannot be taken as definitive evidence, our observations indicate rod precursors are fundamentally different from the cells of the germinal zone, or the embryonic neuroepithelium, and suggest that during retinal ontogeny these cells may have undergone a commitment step (or steps) to the rodcell fate.

In the teleost fish, neurogenesis at the retinal margin represents a spatial recapitulation of embryonic developmental time (Fernald, 1989). The germinal zone serves as a spatially restricted pool of retinal progenitors (Müller, 1952; Blaxter and Jones, 1967; Johns, 1977; Meyer, 1978; Fernald, 1989 ). In the present study, BrdU was used to label the mitotically active cells in the germinal zone and sections through the retina were double-immunostained with antibodies against $\mathrm{BrdU}$ and pax6. This revealed that the BrdU+ cells in the germinal zone were immunostained with the pax6-antibodies, and we interpret this to indicate that these cells contain the pax 6 protein. In addition, as the progeny of the germinal zone cells differentiate, there is a progressive restriction of the pax 6 immunolabel to those cells destined for the nascent INL and the GCL. The pax6 immunolabeling of the cells of the germinal zone and the adjacent, differentiating retina is qualitatively similar to the pax6 expression in the embryonic vertebrate retina (see before). The pattern of pax 6 expression in the retina matches the general pattern of pax6 expression in other regions of the CNS: expression first in mitotically active cells followed by a progressive restriction to subsets of postmitotic neurons as cellular differen- tiation begins (Stoykova and Gruss, 1994). In the retina pax6 may have a broad functional role common to both developing and mature neurons. Alternatively, this molecule may have different regulatory functions during different stages of development (see Stoykova and Gruss, 1994).

The present study also revealed that in lesioned retinas many proliferating cells of the regenerative blastema are pax6+. At 5 days postlesion, the first neuroepithelial-like cells first began to appear, and these cells were pax6+. By 7 days postlesion, pax6+ cells were numerous and organized into clumps or radial clusters that spanned both the INL and ONL. At both 5 and 7 days postlesion, these pax $6+$ cells could be labeled with BrdU, identifying them as the progenitors of the regenerated neurons (see Hitchcock et al., 1992). The pax6 protein was not a general marker of mitotically active cells, however. We observed faintly stained cells in the outer INL at 3 days postlesion, prior to the onset of cell proliferation. These cells had the appearance of mature neurons, and their laminar position suggested they may be bipolar or Müller glial cells. Based on their morphology and lack of BrdU label, we tentatively assume that these cells do not give rise to the pax $6+/ \mathrm{BrdU}+$ cells of the blastema, although we cannot exclude this possibility. At 5 and 7 days postlesion, singly labeled cells (pax6 $+/ \mathrm{BrdU}-$ or pax6-/BrdU+) were also seen. Pax $6+$ cells lacking the BrdU label were seen infrequently and are perhaps neuronal progenitors that were not synthesizing DNA during the time the BrdU was available for uptake, and therefore were not stained by the BrdU-antibodies. BrdU+ cells lacking the pax 6 label were much more numerous and were generally present within the ONL surrounding the wound, but their identities also cannot be conclusively determined. We envision three possibilities: First, these could be cells that withdrew from the mitotic cycle or became committed to a particular fate and stopped synthesizing pax6 subsequent to the BrdU injections; second, these cells could be microglial or Müller glial cells (see later), which do not contain pax6, that were stimulated to divide; third, these cells could be pax6-, rod precursors, which were stimulated to synthesize DNA due to their proximity to the injury or due to the incidental destruction of rod photoreceptors adjacent to the incision through the eye (see Henken and Yoon, 1989; Hitchcock et al., 1992; Braisted and Raymond, 1993). We favor this latter possibility, but the absence of any markers specific for rod precursors precludes us from confirming or refuting this. 
In teleost fish the source of regenerated neurons has yet to be conclusively identified. Three lines of evidence implicate rod precursors, although other cells within the retina remain viable candidates: First, rod precursors are the only mititocally active cells in mature retina whose progeny are neurons. Second, rod precursors respond to retinal injuries. For example, crushing the optic nerve stimulates a transient up-regulation in DNA synthesis in these cells (Henken and Yoon, 1989; Owusu-Yaw et al., 1990 ). Third, in the goldfish retina neuronal regeneration is elicited only if cellular destruction includes the ONL, where rod precursors are sequestered (Raymond et al., 1988; Braisted and Raymond 1993). This piece of evidence is the most compelling. Complete destruction of neurons in both the INL and GCL does not elicit regeneration if photoreceptors are spared (Raymond et al., 1988), and lesions restricted to just the ONL result in the regeneration of rod and cone photoreceptors (Braisted et al., 1994). If rod precursors are the antecedents of the pax $6+$ cells of the blastema, our data indicate that injury to the retina causes a change in pax6 expression and (perhaps) fate of these cells, from not expressing pax 6 and producing rods exclusively to expressing pax6 and giving rise to retinal neurons of all phenotypes.

Cells other than rod precursors may give rise to regenerated neurons, however, and recent evidence points to cells resident within the INL. We have observed that following surgical lesions to the goldfish retina, cells within the INL, distant from the lesion, are occasionally labeled with BrdU (Hitchcock, unpublished observations, see also Cameron and Easter, 1995), and in the present study, at the onset of the injury-induced proliferation, BrdU $+/$ pax $6+$ cells were always present within the INL adjacent to the retinal wound. Negishi et al. (1991a, 1991b) and Negishi and Shinagawa (1993) have demonstrated that in fish intraocular injections of neurotoxins or putative mitogens stimulate DNA synthesis within the INL. Finally, Braisted and Raymond (1994) have shown that in the goldfish, after destruction of photoreceptors by laser lesions, the nuclei of Müller glial cells are present in the lesioned ONL, and some of these cells can be labeled with $\mathrm{BrdU}$ ( see also Lessell et al., 1980).

Our previous studies of retinal regeneration (Hitchcock et al., 1992; Hitchcock and Cirenza, 1994; Hitchcock and VanDeRyt, 1994) qualitatively and quantitatively compared the cellular and synaptic anatomy of regenerated and normal retina. Collectively, these studies indicated that the anatomy of regenerated retina closely approximates the normal retina. From this, we concluded, broadly stated, that in the goldfish common cellular and molecular events must underlie both retinal ontogeny and retinal regeneration. The results of the present study provide direct evidence to support this conclusion. Pax6, synthesized in progenitors during retinal neurogenesis, is synthesized in the injury-induced progenitors during retinal regeneration. This implies, irrespective of the antecedents of the regenerative progenitors, that injury induces expression of pax6. This presumably occurs via molecules whose release or synthesis is stimulated by injury to the retina. Consistent with this, the application of nerve growth factor and brain-derived neurotrophic factor can induce pax6 expression in primary cultures of cerebellar neurons (Kioussi and Gruss, 1994). An important next step will be to identify the molecules and their cellular source that initiate regeneration and the expression of pax6 in the teleost retina.

The authors thank the following individuals who contributed to this study: Drs. S. S. Easter, Jr., P. A. Raymond, K. Barald, and members of the Hitchcock laboratory for reading earlier versions of the manuscript; Drs. A. Fjose, S. Krauss, and I. Mikkola for generously providing the pax6 antibodies; Dr. C. Barnstable for providing the HPC- 1 antibody; P. Cirenza and M. Gillett for providing technical support; and D. Giebel for providing secretarial support. The data for this study were collected, in part, while P.F.H. was a visitor at Kings College. The hospitality of the members of the Developmental Biology Research Center is gratefully acknowledged. This study was supported by National Institutes of Health grants EY07060 and EY07003 (CORE) to P.F.H., a National Science Foundation training grant to J.T.V. and an SERC program grant to S.W.W., N. Holder, and M. Maden. S.W.W. is a Wellcome Trust Senior Research Fellow. P.F.H. is a Research to Prevent Blindness William and Mary Greve International Research Scholar.

\section{REFERENCES}

AL, M. A. (1976). Stretching of the retina during growth of salmon (Salamo salar), Growth 28:83-98.

BALling, R., Deutsch, U., and Gruss, P. (1988). Undulated, a mutation affecting the development of the mouse skeleton, has a point mutation in the paired box of Pax-1. Cell 55:531-535.

Barnstable, C. J., Hofstein, R., and Akagawa, K. (1985). A marker of early amacrine cell development in rat retina. Brain Res. 352:286-290.

BEEBE, D. C. (1994). Homeobox genes and vertebrate 
eye development. Invest. Ophthalmol. Vis. Sci. 35: 2897-2900.

BLAXTER, J. H. S. and JONES, M. P. (1967). The development of the retina and retinomotor responses in the herring. J. Marine Biol. Assoc. UK 47:677-697.

BLOOMFIELD, S. A. and HitchCOCK, P. F. (1991). Dendritic arbors of large-field ganglion cells show scaled growth during expansion of the goldfish retina: a study of morphometric and electroronic properties. J. Neurosci. 11:910-917.

Bopp, D., BURri, M., Baumgartner, S., Frigerio, G., and NOLL, M. (1986). Conservation of a large protein domain in the segmentation gene paired and in functionally related genes of Drosophila. Cell 47:10331040.

BRAISTED, J. E. and RAYMOND, P. A. ( 1992). Regeneration of dopaminergic neurons in goldfish retina. $D e-$ velopment 114:913-919.

Braisted, J, E. and RAYmond, P. A. (1993). Continued search for the cellular signals that regulate regeneration of dopaminergic neurons in goldfish retina. Dev. Brain Res. 76:221-232.

BRaisted, J. E., Essman, T. F., and Raymond, P. A. (1994). Selective regeneration of photoreceptors in goldfish retina. Development 120:2409-2419.

Cameron, D. A. and Easter, S. S., Jr. (1995). Cone photoreceptor regeneration in adult fish retina: phenotypic determination and mosaic pattern formation. $J$. Neurosci. 15:2255-2271.

Del Rio-Tsonis, K., Washbaugh, C. H., and TSONIS, P. A. (1995). Expression of pax-6 during urodele eye development and lens regeneration. Proc. Natl. Acad. Sci. USA 92:5092-5096.

Dowling, J. E. and EHringER, B. (1978). The interplexiform cell system I. Synapses of the dopaminergic neurons of the goldfish retina. Proc. $R . S o c$. Lond. $B$. 201:7-26.

Epstein, D. G., Vekemans, M., and Gros, P. (1991). Splotch $(\mathrm{Sp} 2 \mathrm{H})$, a mutation affecting development of the mouse neural tube, shows a deletion within the paired homeodomain of Pax-3. Cell 67:767-774.

FERNALD, R. D. (1989). Retinal rod neurogenesis. In: Development of the Vertebrate Retina. B. L. Finlay and D. E. Sengelaub, Eds., Plenum Press, New York, pp. $31-42$.

Frigerio, G., Burri, M., Bopp, D., Baumgartner, S., and NOLL, M. (1986). Structure of the segmentation gene paired and the Drosophila PRD gene set as part of a gene network. Cell 47:735-746.

Glaser, T., Walton, D. S., and MaAs, R. L. (1992). Genomic structure, evolutionary conservation and aniridia mutations in the human PAX6 gene. Nat. Gen. 2:232-238.

Goulding, M. D., Lumsden, A., and Gruss, P. (1993). Signals from the notochord and floor plate regulate the region-specific expression of two $\mathrm{Pax}$ genes in the developing spinal cord. Development 117: 1001-1016.
Gruss, P. and Walther, C. (1992). Pax in development. Cell 69:719-722.

HAGEDORN, M. and FERNALD, R. D. (1992). Retinal growth and cell addition during embryogenesis in the teleost, Haplochromis burtoni. J. Comp. Neurol. 321: 193-208.

Halder, G., Caliaerts, P., and W. J. Gehring (1995). Induction of ectopic eyes by targeted expression of the eyeless gene in Drosophila. Science 267: 1788-1792.

Henken, D. B. and Yoon, M. G. (1989). Optic nerve crush modulates proliferation of rod precursors cells in the goldfish retina. Brain Res. 501:247-259.

Hill, R. E., Favor, J., Hogan, R. L. M., TON, C. C. T., Saunders, G. F., Hanson, I. M., Prosser, J., JorDaN, T., Hastie, N. D., and VAN Heyningen, V. (1993). Mouse Small eye results from mutations in a paired-like homeobox-containing gene. Nature 354: 522-525.

HitcHCOCK, P. F. (1989). Exclusionary dendritic interactions in the retina of the goldfish. Development 106:589-598.

Hitchcock, P. F. and Cirenza, P. (1994). The synaptic organization of regenerated retina in the goldfish. J. Comp. Neurol. 343:609-616.

HITCHCOCK, P. F. and S. S. EASTER, JR. (1986). Retinal ganglion cells in goldfish: a qualitative classification into four morphological types, and a quantitative study of he development of one of them. J. Neurosci. 6:1037-1050.

HITCHCOCK, P. F. and RAYMOND, P. A. (1992). Retinal regeneration. Trends Neurosci. 15:103-108.

HITCHCOCK, P. F. and VANDERYT, J. T. (1994), Regeneration of the dopamine-cell mosaic in the retina of the goldfish. Visual Neurosci. 11:209-217.

HITCHCOCK, P. F., LINDSEY MYHR, K. J., EASTER, S. S., JR., MANGIONE-SMITH, R., and DWYER JONES, $D$. (1992). Local regeneration in the retina of the goldfish. J. Neurobiol. 23:187-203.

HitCHCOCK, P. F., MACDONALD, R. E., WilsON, S. W., and VANDERYT, J. T. (1994). Pax6 gene expression in normal and regenerating retina of the goldfish. Soc. Neurosci. Abstr. 20:1322.

JOHNS, P. R. (1977). Growth of the goldfish eye. III. Source of new retinal cells. J. Comp. Neurol. 176:343357.

JOHNS, P. R. (1982). Formation of photoreceptors in larval and adult goldfish. J. Neurosci. 2:178-198.

Johns, P. R. and EASTER, S. S., JR . (1977). Growth of the adult goldfish eye. II. Increase in retinal cell number. J. Comp. Neurol. 176:331-341.

JOHNS, P. R. and FERNALD, R. D. (1981). Genesis of rods in teleost fish retina. Nature 293:141-142.

Jordan, T., Hanson, I., Zaletayev, D., Hodgson, S., Prosser, J., Seawright, A., Hastie, N., and Van HEYNINGEN, V. (1992). The human PAX6 gene is mutated in two patients with aniridia. Nat. Gen. 1: $328-332$. 
Keller, S. A., Jones, J. M., Boyle, A., Barrow, L. L., Killen, P. D., Green, D. G., Kapousta, N. V., HitchCock, P. F., Swank, R. T., and MeisLER, M. H. (1994). Kidney and retinal defects $(K r d)$, a transgene-induced mutation with a deletion of mouse chromosome 19 that includes the Pax 2 locus. Genomics 23:309-320.

KIoussi, C. and Gruss, P. (1994). Differential induction of Pax genes by NGF and BDNF in cerebellar primary cultures. J. Cell Biol. 125:417-425.

Knight, J. K. and Raymond, P. A. (1990). Time course of opsin expression in developing rod photoreceptors. Development 110:1115-1120.

KOCH, J.-H. (1982). Neuronal addition and retinal expansion during growth of the crucian carp eye. $J$. Comp. Neurol. 209:264-274.

Krauss, S., Johansen, T., Korzh, V., Moens, U., ERICSON, J. U., and FJOSE, A. (1991). Zebrafish $\operatorname{pax}[\mathrm{zf}-\mathrm{a}]$ : a paired box-containing gene expressed in the neural tube. EMBO J. 10:3609-3619.

KRUZ-ISLER, G. and WOLBURG, H. ( 1982). Morphological study on the regeneration of the retina in the rainbow trout after ouabain-induced damage: evidence for dedifferentiation of photoreceptors. Cell Tissue Res. 225: $165-178$.

Lessel, S., Craft, J. L., and Albert, D. M. (1980). Kianic acid induces mitoses in mature retinal neurons in rats. Exp. Eye Res. 30:731-738.

LEVINE, E. M. and SCHECHTER, N. ( 1993). Homeobox genes are expressed in the retina and brain of adult goldfish. Proc. Natl. Acad. Sci. USA 90:2729-2733.

Levine, E. M., HitchCOCK, P. F., Glasgow, E. and SCHECHTER, N. (1994). Restricted expression of a new paired-class homeobox gene in normal and regenerating adult goldfish retina. J. Comp. Neurol. 348: 596-606.

LiU, I. S., Chen, J., Ploder, L., Vidgen, D., VAN der Kooy, D., Kalinas V., and McInNes, R. R. (1994). Developmental expression of a novel murine homeobox gene ( $C h \times 10)$ : Evidence for roles in determination of the neuroretina and inner nuclear layer. Neuron 13:377-393.

LOMBARDO, F. (1968). La rigenerazione della retina negli adulti di un teleosteo. Accad. Lincei. Rendiconti Sci. Fis. Mat. Nat. 47:631-635.

LOMBARDO, F. (1972). Andamento e localizzazione delle mitosi durante le rigenerazione della retina di un teleosteo adulto. Accad. Lincei. Rendiconti Sci. Fis. Mat. Nat. 53:323-327.

LYALL, A. H. (1957). The growth of the trout retina. $Q$. J. Microsc. Soc. 98:101-110.

Macdonald, R., Xu, Q., Barth, K. A., Mikkola, I., Holder, N., Fjose, A., Krauss, S., and Wilson, S. W. (1994a). Regulatory gene expression boundaries demarcate sites of neuronal differentiation and reveal neuromeric organization of the zebrafish forebrain. Neuron 13:1039-1053.
Macdonald, R., Hitchcock, P. F., Wilson, S. W., and VANDERYT, J. T. (1994b). Pax6 gene expression in the developing and regenerating retina of teleost fish. Invest. Ophthalmol. Vis. Sci. 35(suppl.):1404.

MACK, A. F. and FERnALD, R. D. (1995). New rods move before differentiating in adult teleost retina. Dev. Biol. 170:136-141.

MAiER, W. and WOlburg, H. (1979). Regeneration of the goldfish retina after exposure to different doses of ouabain. Cell Tissue Res. 202:99-118.

Martin, P., Carriere, C., Dozier, C., Quatannens, B., Mirabel, M.-A., Vandenbunder, B., Stehelin, D., and SAULE, S. (1992). Characterization of a paired box- and homeobox-containing quail gene ( $P a x$ $Q N R$ ) expressed in neuroretina. Oncogene 7:17211728.

Matsuo, T., Osumi-Yamashita, N., Nojl, S., Ohuchi, H., Koyama, E., Myokai, F., Matsuo, N., Taniguchi, S., DoI, H., Ninomiya, Y., Fujiwara, M., WATANABE, T., and ETO, K. (1993). A mutation in the PAX-6 gene in rat small eye is associated with impaired migrations of crest cells. Nature Gen. 3:299304.

MEYER, R. L. (1978). Evidence from thymidine labeling for the continuous growth of retina and tectum in juvenile goldfish. Exp. Neurol 59:99-111.

MülleR, H. (1952). Bau und Wachstum der Netzhaut des Guppy (Lebistes reticulatus). Zool. Jb. Abt. Allg. Zool. Physiol. 63:275-324.

Negishi, K. and Shinagawa, S. (1993). Fibroblast growth factor induces proliferating cell nuclear antigen immunoreactive cells in goldfish retina. Neurosci. Res. 18:143-156.

Negishi, K., Teranishi, T., Kato, S., and NAKamura, Y. (1987). Paradoxical induction of dopamine cells following intravitreal injection of high doses of 6-hydroxydopamine in juvenile carp retina. Dev. Brain Res. 37:67-89.

Negishi, K., Sugawara, K., Shinagawa, S., TeraNiSHi, T., KUO, C. H., and TAKASAKI, Y. (1991a). Induction of immunoreactive proliferating cell nuclear antigen (PCNA) in goldfish retina following intravitreal injection of tunicamycin. Dev. Brain Res. 63:71-83.

Negishi, K., Stell, W. K., Teranishi, T., Karkhanis, A., OWUSU-YAW, V., and TAK ASAKI, Y. (1991b). Induction of proliferating cell nuclear antigen (PCNA)immunoreactive cells in goldfish retina following intravitreal injection with 6-hydroxydopamine. Cell. Mol. Neurobiol. 11:639-659.

Noll, M. (1993). Evolution and role of Paxgenes. Curr. Opin. Genet. Dev. 3:595-605.

OWusu-Yaw, V., KYle, A. L., and Stell, W. K. (1992). Effects of lesions of the optic nerve, optic tectum and nervus terminalis on rod precursor proliferation in the goldfish retina. Brain Res. 576:220-230. 
Püschel, A. W., Gruss, P., and Westerfield, M. (1992). Sequence and expression pattern of pax-6 are highly conserved between zebrafish and mice. Development 114:643-651.

QUIRING, R., WALLDORF, U., KLOTER, U., and GEHRING, W. J. (1994). Homology of the eyeless gene of Drosophila to the Small eye gene in mice and Aniridia in humans. Science 265:785-789.

RAYMOND, P. A. (1985). The unique origin of rod photoreceptors in the teleost retina. Trends Neurosci. 8: 12-17.

RAYMOND, P. A. (1991). Retinal regeneration in teleost fish. In: Regeneration of Vertebrate Sensory Receptor Cells (Ciba Foundation Symposium). G. R. Bock and J. Whelan, Eds., John Wiley \& Sons, Chichester, pp. 171-191.

Raymond, P. A. and RivLin, P. K. (1987). Germinal cells in the goldfish retina that produce rod photoreceptors. Dev. Biol. 122:120-138.

RAYMOND, P. A., Reifler, M. J., and Rivlin, P. K. (1988). Regeneration of goldfish retina: rod precursors are a likely source of regenerated cells. J. Neurobiol. 19:431-463.

SANDY, J. M. and Blaxter, J. H. S. (1980). A study of retinal development in larval herring and sole. $J$. Marine Biol. Assoc. UK 60:59-71.

Sanyanusin, P., Schimmenti, L. A., MCNoE, L. A., Ward, T. A., Peir Pont, M. E. M., Sullivan, M. J., DOBYNS, W. B., and ECCLES, M. R. (1995). Mutation of the $P A X 2$ gene in a family with optic nerve colobomas, renal anomolies and vesicuoreteral reflux. Nat. Gen. 9:358-363.

Stoykova, A. and Gruss, P. (1994). Roles of paxgenes in developing and adult brain as suggested by expression patterns. J. Neurosci. 14:1395-1412.

Strachan, T. and Read, A. P. (1994). PAX genes. Curr. Opin. Gen. Dev. 4:427-438.

Ton, C. C., Hirvonen, H., Miwa, H., Weil, M. M., Monaghan, P., Jordan, T., van Heyningen, V., Hastie, N. D., Meijers-Heijboer, H., Dreschler, M., Royer-Pokora, B., Collins, F., Swaroop, A., Strong, L. C., and Saunders, G. F. (1991). Positional cloning and characterization of a paired boxand homeobox-containing gene from the Aniridia region. Cell 67:1059-1074.

Walther, C. and Gruss, P. (1991). Pax-6, a murine paired box gene, is expressed in the developing CNS. Development 113:1435-1449. 